\title{
WRITING FROM OTHER MARGINS. DIFFERENCE, EXCEPTION, AND TRANSLATION IN THE PORTUGUESE-SPEAKING WORLD: COUNTERPOINTS BETWEEN LITERARY REPRESENTATIONS AND CRITICAL PARADIGMS
}

\author{
Elena Brugioni* \\ Universidade de Campinas
}

\begin{abstract}
Translation as a conceptual framework for the study of the so-called Postcolonial Literatures represents a complex critical paradigm that opens up a number of theoretical paths with which to read and place literary representations within a global perspective. Regarding what can be defined as African Europhone Literatures (Zabus, 2007), the concept of translation offers the possibility of problematizing several critical issues, particularly those relating to questions of "cultural difference" (Bhabha, 1994) and, thus, the textual "embodiment of the other" (Ahmed, 2000). In this respect, translation becomes an operational concept not only for a textual hermeneutic, but also for a wider epistemological reflection, allowing for a discussion of paradigms that characterize the critical reception of the African novel, and therefore the very field of African literary criticism. Through the exploration of authors and texts from the so-called Lusophone African Literatures, this article aims to draw a critical journey that highlights the theoretical possibilities that the concept of translation can offer, in order to address literary representations as crucial "epistemological experiences" (García Canclini, 2012, 50) with which to read and understand changes, challenges and transformations of our time.
\end{abstract}

* Elena Brugioni: MA in Modern Literatures (2004) from the University of Bologna (UNIBO), Italy. PhD (2009) in Lusophone African Literatures from the University of Minho, Portugal. She is Professor of African Literatures and Postcolonial Studies at the Department of Literary Theory of the University of Campinas (Unicamp), Brazil. E-mail: elena@iel.unicamp.br 
Keywords: Portuguese-Speaking World. African Literatures. Postcolonial Theory. Translation.

\title{
ESCREVENDO A PARTIR DE OUTRAS MARGENS. DIFERENÇA, EXCEÇÃO E TRADUÇÃO NO MUNDO DE LÍNGUA PORTUGUESA: CONTRAPONTOS ENTRE REPRESENTAÇÕES LITERÁRIAS E PARADIGMAS CRÍTICOS
}

\begin{abstract}
Resumo: Enquanto enquadramento conceptual para estudar as chamadas literaturas pós-coloniais, a tradução constitui um paradigma crítico complexo que abre inúmeros caminhos teóricos a partir de onde ler e situar as representações literárias sob uma perspetiva global. No que concerne ao que pode ser definido como literaturas africanas eurófonas (Zabus, 2007), o conceito de tradução oferece a possibilidade de problematizar diversas questões críticas, em particular as que dizem respeito à "diferença cultural" (Bhabha, 1994) e, por isso, à "materialização [textual] do outro" (Ahmed, 2000). Neste sentido, a tradução torna-se um conceito operativo não apenas para uma hermenêutica textual, mas também para uma reflexão epistemológica mais ampla, permitindo discutir os paradigmas que caracterizam a receção crítica do romance africano e, portanto, o próprio campo da crítica literária africana. Através da análise de autores e textos provenientes das chamadas literaturas africanas lusófonas, o presente artigo visa traçar um percurso crítico que destaque as possibilidades teóricas que o conceito de tradução oferece, de modo a que as representações literárias possam ser abordadas como "experiências epistemológicas” cruciais (García Canclini, 2012, 50), a partir das quais se pode ler e compreender as alterações, os desafios e as transformações do nosso tempo.
\end{abstract}

Palavras-chave: Mundo de Língua Portuguesa. Literaturas Africanas. Teoria Pós-colonial. Tradução. 
Yet language is not everything. It is only a vital clue to where the self loses its boundaries.

(Spivak, 1993)

\section{Translating the postcolonial fracture}

Translation as a conceptual framework for the study of the socalled "Postcolonial Literatures" (Bhabha 1994, Robinson 1997, Bassnett \& Trivedi 1999, Apter 2006) represents a complex paradigm that puts forward a number of underexplored theoretical paths to read and place literary representations within a broader critical perspective and therefore problematize the concept of translation within the very field of African literary criticism. Among the diversified and complex production that characterizes the theoretical formulations of the field of Translation Studies, it is worth singling out its importance for postcolonial epistemological approaches to literary and cultural texts. These approaches are particularly relevant for the analysis of texts and narratives that (re) present what has been defined as cultural difference, and offer the possibility to redefine the critical and aesthetic value of translation within African literary writing.

The concept of translation that I would like to address in this article is not simply concerned with a linguistic dimension, but sees translation as an aesthetic and political writing strategy, "a significant medium of subject re-formation and political change" (Apter 2006, 10), built through a process that involves a plurality of cultural and creative repertoires, and suggests an interesting intersection with other theoretical constellations, such as transculturation (Pratt 1992, Rama 2001) and transnationalism (Hitchcock 2010, Lionnet \& Shih 2005). On a wider disciplinary perspective, as Emily Apter points out:

Translation becomes the name for the ways in which the humanities negotiate past and future technologies of 
communication, while shifting the parameters by which language itself is culturally and politically transformed. By insisting, too, on learning languages wholly distant from one's native philology, a new comparative literature based on transnational pedagogies renews the physic life of diplomacy, even as it forces an encounter with intractable alterity, with that which will not be subject to translation. $(2006,11)$

Regarding Portuguese-speaking contexts, translation - as a critical metaphor (Bandia 2008) - becomes a very productive framework to address a number of questions and aspects related to what is usually defined as "Lusophone African Literatures" and particularly concerning the linguistic question or, in a far more provocative way, the linguistic obsession that seems to haunt the Portuguese “(post)imperial house", to paraphrase Gilberto Freyre's canonical text, Casa-grande \& senzala (1933). However, it is not my intention here to address the many questions and problems related to the Lusophone ideology that sometimes informs the field of African Literary Studies in Portugal and in other Portuguese-speaking contexts. At the same time, it is, in my opinion, very important to address some aspects of the Lusophone linguistic question in order to emphasize the conceptual value and the epistemological importance of translation to promote a decolonized critical reading and reception of contemporary African writing in Portuguese. This approach highlights the political and cultural significance of these writings within a postcolonial theoretical and epistemological perspective, bearing in mind, as Ana Paula Ferreira points out, that "as the very ground of colonial relations and their reproducibility after independence, the European language then and now, there and here, is what can hardly be avoided: it constitutes the very fabric of (post)coloniality" $(2007,28)$. In this respect, the effective conceptualization of a "Lusophone community" represents the ground against which the (post)colonial disquiet and resentment that appear to run through different aspects of Portuguese social, 
cultural and political life and public space may be tackled, while addressing linguistic identity and ideology from the perspective of what Pascal Blanchard defines as "the colonial fracture" (2005):

Defining the colonial fracture in all its dimensions is not simple. This concept attempts to, simultaneously, make sense of the tension and the effects of postcolonialism, and to cover multiple realities and heterogeneous situations. These realities and situations can, to a certain extent, be considered as taking into account the long-term processes related to the colonial situation. Therefore, one should not look for systematic coherence amongst the effects of this fracture, for it affects different fields in different ways, which are not necessarily related. (Blanchard 2005, 13; my translation)

In this sense, the aim of the reflection proposed in this text is to address translation as a conceptual paradigm and, simultaneously, an epistemological framework within the field of African Literary Studies, and attempt to provide a counterpoint between Postcolonial Theory, African literary criticism and Portuguese-speaking African writing. In this process, it is necessary to underline how translation represents a crucial critical tool to read and understand a variety of aesthetic practices that are inscribed in the so-called "Lusophone African Literatures", and how it contributes to deconstruct discourses of exoticism and authenticity that sometimes characterize the reception of African literary writing within Western contexts.

\section{Counterpoints: African writing, postcolonial readings}

My interest in Translation Studies, most likely due to my research in the field of Comparative African Literatures and Postcolonial Theory, is mainly related with the conceptual dimension of Translation - in other words, translation as a theoretical paradigm -, 
and therefore with the epistemological potential that the conceptual articulation of this paradigm can offer in order to analyse specific aspects of contemporary African writing, particularly those that concern questions of "cultural difference" (Bhabha 1994), and, thus, the "issue" of what, to use Sara Ahmed's words, I would like to refer to as "the textual embodiment of the other" (2000). In this sense, translation becomes an operational concept not only for a textual hermeneutic, but also for a wider epistemological reflection, allowing for a discussion of paradigms that characterize the reception of the African novel, and therefore the very field of African literary criticism. In fact, considering the reception of authors and texts that perform cultural and political difference as is the case with the African novel -, a further aspect, which appears to be particularly relevant, is the legitimization process of African authors and texts within the so-called Western critical and publishing contexts. This aspect is particularly relevant with regard to the relation between this process and the canon of African Studies, which can be equated with what Harry Garuba defines as "strategic clusters of reception" (2008) raised by the affirmation of African writing within hegemonic networks. As far as reception in a broader perspective is concerned, we can easily notice, at least since the 1980s, the rise of a mass critical response and institutional consecration of certain African texts and authors - especially Anglophone and Francophone -, which have contributed to the development of a specific field of knowledge characterized by its own theoretical discourse. ${ }^{1}$ With the rise of Postcolonial Studies, a rather interesting intersection between Postcolonial Theory and African Literatures has come to provide the opportunity to address the dissemination of African texts as differential cultural products on a large scale - outside a field of specialization -, and

\footnotetext{
${ }^{1}$ In other words, as Harry Garuba puts it: "[T]he critical reception of the African novel has led to the construction of a field of knowledge in which the conventional terms of novelistic discourse are reconceptualized and reconfigured in relation to other (African) forms of traditions of verbal expression and other (African) social and historical contexts, which generate different questions and thus call for different grammars of discourse" $(2009,243)$.
} 
thus to approach so-called postcolonial epistemologies with their own specific theoretical and operational frameworks. Generally speaking, the institutional affirmation of postcolonial critique - at least within Anglophone contexts - and, as Simon Gikandi says, "its desire to make the postcolonial space the centre of its concerns and preoccupations" $(2004,118)$ have determined an ambiguous process of dissemination and affirmation of African authors and texts that suggest the idea that African literary representations must be, as Peter Hallward puts it, "absolutely postcolonial" (2001). Regarding this disciplinary intersection, Benita Parry notes:

\begin{abstract}
Already a canon of "Postcolonial Literature" is formed in which the marvellous and the magic realisms of Latin America, Caribbean, African, and Asian writing [...] are given greater prominence than those closer to "realist" modes. [...] The privileging of novelistic styles which animate a postcolonial identity as fissured, unstable, and multiply located can be related to manifest preference of the postcolonial discussion for mestizo or creolized formations, the corollary of which is a tendency to scant the intelligibility, mutability, and inventiveness of the indigenous (Brennan 1997). (2004, 73)
\end{abstract}

Furthermore, when considering what can be defined as "cultural field" as a whole - following the definition proposed by Pierre Bourdieu (1993) - we could go on to say, as Aijaz Ahmad does, that "when cultural criticism reaches this point of convergence with the universal market, one might add, it becomes indistinguishable from commodity fetishism" $(1992,217)$. Moreover, this kind of commodification seems to be particularly relevant for African literary writing, as has been well demonstrated by Graham Huggan in his prominent study regarding the process of "marketing the margins" as the Postcolonial Exotic: "[A] pathology of cultural representations under late capitalism - a result of the spiralling commodification of cultural difference, and of response to it, that 
is characteristic of the (post)modern, market-driven societies in which many of us currently live" $(2001,33)$.

An emblematic example of marginality and the commodification of cultural difference in Lusophone critical contexts is that the Portuguese publishing house where most of the authors from Portuguese-speaking African countries are published - Editorial Caminho - has called its African catalogue "Outras Margens" [Other Margins], drawing a transnational imaginary within the Portuguese-speaking World characterized by the spatial dichotomy of the centre and its margins, and thus conveying the idea of a "Lusophone literary field" that signifies what seems to be still a neo-colonial framework. ${ }^{2}$ It is, therefore, evident how the language - to quote Ferreira again - represents the very ground of both colonial and postcolonial relations (2007). At the same time, the recent debate among some of the most prominent figures of African cultural critique, such as Achille Mbembe or Binyavanga Wainaina, regarding what has been defined as "Afropolitanism"3 (Mbembe 2007) seems to (re)address, under a new perspective, the problems of Western legitimization and reception of African cultural products, raising once again the question of the intersection between capitalist market processes, literary and cultural production and critique, where the role of Postcolonial Studies is undeniably significant.

Despite the dangers posed by the relationship between Postcolonial Studies and differential literary and cultural products - such as the African novel -, postcolonial critique has determined an essential "epistemological turn" motivating crucial changes

\footnotetext{
${ }^{2}$ The title of this text - "Writing from other Margins" - has been chosen with the intention of suggesting exactly this sort of critical problematization.

${ }^{3}$ Regarding the concept of “Afropolitanism”, see: Mbembe 2007, Wainaina 2012, and the South African magazine Afropolitan at http://www.afropolitan.co.za. The analysis of the recent debate, raised within the field of African Studies concerning the relationship between Pan-Africanism and Afropolitanism, offers the possibility to problematize the relation between a "Global Africa" and "Africa in the World" (Mbembe 2006) in contrast with the process of "cultural commodification" (Wainaina 2012) that the Afropolitan trend seems to signify in a critical perspective.
} 
within the Humanities, and contributing to a significant shift in the practices that have framed the reception of the African novel. On this subject, Harry Garuba writes:

The strategic clusters of critical interest were kept alive within the domain of postcolonial theory. [...] Not only was the authority of colonial discourse being questioned, the categories of nationalistic discourse were also repudiated. The unified subjects of colonialist and nationalist discourse become fragmented and dispersed, written over by ambivalence, ambiguity and hybridity. $(2009,256)$

Postcolonial theory thus becomes a fundamental critical gesture within the very field of African literary criticism, pointing to a number of conceptual clues that, despite the sophistication of its critical discourse, contributes to the emergence of "new" and "alternative" frameworks with which to read and place literary and cultural representations. At the same time, as Benita Parry has drawn attention to:

The task facing postcolonial studies [and, I would add, African Literary Criticism] today is not, of course, to abandon the theoretical sophistication that has marked its engagement with Orientalist discourse, Eurocentrism, and the exegetics of representation, but to link such meta-critical speculations with studies of actually existing political, economic, and cultural conditions, past and present. $(2004,80)$

Linking the sophistication of postcolonial discourses with the material conditions of the contexts in which texts are placed is the challenge that, in my opinion, new critical clusters within Postcolonial Theory and African Literary and Cultural Studies are dealing with, particularly with regard to the occurrence of 
alternative categories of analysis. The emergence, for instance, of new critical articulations regarding spatiotemporal frameworks offer the possibility of intersecting several critical questions that highlight the process of "remapping the unmappable" - as Peter Hitchcock would say $(2010,36)$ - that postcolonial writing seems to achieve, allowing for a critical reading that does not place the writing and its meaning within the perspective of "illustrations", but rather as crucial "epistemological experiences" - to use Nestor García Canclini's words $(2012,50)$ - with which to read and understand changes and the challenges of our time. In this light, the relation between translation and the spatiotemporal framework becomes an immensely relevant intersection both for textual reading and for the wider field of literary criticism because, as Peter Hitchcock points out:

The politics of translation are deeply inscribed in the long space not just because it informs how, for instance, the work of [Assia] Djebar comes to circulate transnationally, but because time/space is an instantiation of what Emily Apter calls "translatio", the core of comparativism's very possibility as a literary horizon. [...] since whether criticism calls itself "comparative" or "postcolonial" it necessarily reveals the extent to which the language is resituated by chronotopic coordinates, how the writer makes language signify place and time whatever its putative origins. $(2010,41)$

A similar conceptual articulation could be used to arrive at an alternative space-time framework for the study, for instance, of Mozambican literature via what has been defined as the critical paradigm of the Indian Ocean (Hofmeyr 2007, Chaves 2002, Noa 2012 and 2014, Falconi 2013, Brugioni 2013). Through this conceptual perspective a number of "silent" dialogues and counterpoints - inside and outside the limits of the Mozambican nation - can be found, opening up old and new imaginaries that could possibly "emerge" via the sea, and thus remind us that, as 
João Paulo Borges Coelho states: "Behind so many names, so many intersections, and so much diversity, it is always the same, the sea". ${ }^{4}$ Furthermore, the paradigm of the Indian Ocean would provide relational perspectives still undeveloped to approach literary writing and cultural representations in a transnational dimension, and determine a redefinition of the semantic and cultural repertoires summoned and appointed by this literature, while contributing to the reconfiguration of the relationship between literary medium and contextual specificities. As far as the so-called "Indian Ocean perspective" is concerned, translation becomes a crucial epistemological framework in order to address a "network of dynamic and structured relationships" (Chaundhury 1990) between "worlds" that are always already separate and yet contiguous, and thus promoting new and alternative readings within the so-called African Literary and Cultural Studies.

\section{Translating (from) other margins. Examples from the Portuguese-speaking African World}

In order to address this kind of theoretical reflection within the Portuguese-speaking critical context, I would like to start with the example ${ }^{5}$ - as Giorgio Agamben would say (1995) - of an established "Lusophone" African author, the Mozambican writer Mia Couto. Couto's literary work offers the possibility of addressing a number of critical questions, particularly regarding the concept of cultural translation, as a strategy to produce

\footnotetext{
${ }^{4}$ Original quote: "Por trás de tantos nomes, de tantos cruzamentos, e de tanta diversidade, é sempre o mesmo, o mar" (Borges Coelho 2005, 10; my translation).

5 The category of "example", as it has been theorized by Giorgio Agamben (1995), is particularly useful regarding Mia Couto's literary writing, due to the link that it seems to establish with similar linguistic features that characterize other African authors, which suggest the dimension of the "exclusive inclusion" (Agamben 1995, 26) of Couto's literary work within a broader - African - perspective. In this sense, Couto's writing is exemplary to the extent that it "exhibits its belonging to a normal case, [becoming] a paradigm in the etymological sense of the term" (27).
} 
otherness and hybridity as determined by the linguistic features that characterize his writing, and thus addressing the relation between the field of African Literary Study in articulation with the so-called postcolonial critique.

Within the Portuguese-speaking literary context, Mia Couto is considered one of the most typical examples of what Benita Parry defines as Postcolonial Literary Canon, and his writing is usually read through the "corollary of hybridity" - still quoting Parry (2004) - which underlines the process of negotiation and inscription that defines translation within the theoretical discussion proposed by Homi Bhaba (1994). It consists of an original literary oeuvre where translation become a liminal practice of hybridization (Bhabha 1994) that takes place particularly through Couto's peculiar use of the Portuguese language. Despite the need to read Couto's work within the so called "colonial situation" (Balandier 1951, 2007), the critical reception of Couto's literary work is prone to frequent ambiguous readings that assume, on the one hand, that the linguistic features of his writing are a way to demonstrate the potential of the Portuguese language, and, on the other hand, that it is a process that reproduces the Portuguese language as it is spoken in Mozambique. ${ }^{6}$ In both cases, the critical problem raised by this kind of reading is based on an immediate equivalence between literary representations and the very context in which this writing is placed and inscribed. It is not a reception determined by the material conditions of its production, as suggested by Parry, but a reading that implies "risky" relationships that end up proposing an "exotic" definition of Couto's creative project (Brugioni 2012). On the contrary, what Mia Couto's writing seems to suggest is a rather different process that takes place within his writing, and corresponds to a far more complex conceptual, and therefore philosophical, understanding of language. On this matter, the author states:

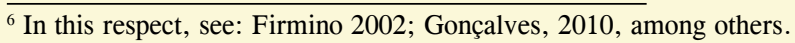


Writing is a house that I visit but where I don't wish to live. What instigates me are the other tongues and languages, knowledge that we earn only if we are able to erase ourselves. From my mother tongue I seek to reach that moment when language is left speechless and becomes a body that doesn't obey rules or structures. What I want is a sort of grammatical faint in which the Portuguese language loses all its senses. In that moment of chaos and loss, the language is permeable to other reasons, it allows itself to be hybridized and becomes more fertile. ${ }^{7}$ (Couto 2009, 196-197)

Critical and, thus, political implications of this kind of poetical and ideological views become very significant within a contextual perspective marked by the "postcolonial situation" (Balandier 2007), and allow for a critical reading inevitably linked with the concepts of "difference" and "exception". It is in fact by reading Mia Couto's linguistic features against the grain that an original critical articulation can emerge regarding processes and political meanings of Couto's literary writing and tackle language in its dimension within the postcolonial exception. In other words, considering the ideological and the political value that characterizes language in a postcolonial situation, the concept of "exception", as it has been defined by Giorgio Agamben (1995), seems to highlight the complex network of relationships that are established in and throughout language, particularly with regard to phenomena of inclusion/exclusion as established by the language itself, and through which language can also be approached. It is, in fact, in

\footnotetext{
${ }^{7}$ Original quote: “A escrita é uma casa que eu visito mas onde não quero morar. O que me instiga são as outras línguas e linguagens, sabedorias que ganhamos apenas se de nós mesmos nos soubermos apagar. Da minha língua materna eu aspiro esse momento em que ela se desidioma, convertendo-se num corpo sem mando de estrutura ou de regra. O que eu quero é este desmaio gramatical, em que o português perde todos os sentidos. Neste momento de caos e perda, a língua é permeável a outras razões, deixa-se mestiçar e torna-se mais fecunda" (Couto 2009, 196-197). The quote has been translated in collaboration with Professor David Brookshaw, eminent translator of Mia Couto's literary work in English, and I would like to thank him for his help and kindness.
} 
and throughout language that "the postcolonial fracture" (Blanchard 2005) becomes aesthetically visible and politically relevant, and transforms language into a "device", as Michel Foucault would say, in order to "break and move away from the dominant one" (Basto 2006). What emerges in this work that "happens in the language but exceeds it" - as Ana Mafalda Leite notes (2003) corresponds, in a phenomenological dimension, to an "othered language" - beyond the European and the Mozambican norms built through a process of translation that sets the literary text as the result of a practice of "trans-Lation" and "trans-Nation" - as Emily Apter would say (2006) - necessarily grounded in a logic of remains and loss, and marked, as Giorgio Agamben puts it, by a phenomenological feature that is simultaneously potential and residual $(1998,127 \mathrm{ff}$.). Therefore, the "language as remains" that arises from this theoretical perspective configures itself as a place where "[the dialectic relation between the norm and the anomie] has been lost entirely" (127; my translation), and thus suggests the use of a "dead language" (Agamben 1982, 48 and 1998, 150ff.). This sort of conceptual constellation not only underlines the potential of language in literary discourses - avoiding a set of epistemological unfeasible dichotomies, such as authenticity and exotic critical discourses, but also enables the definition of language as postcolonial exception, and the theoretical framework of translation as the epistemological and critical paradigm to (re)think the changes and challenges of contemporary secular Postcolonial Humanism. In this sense, translation is not only a linguistic strategy, but it also performs the function of an aesthetic and political practice where negotiation between heterogeneous linguistic and cultural elements is provided by the inscription, in the Portuguese language, of a plurality of codes and repertoires, achieving what Chantal Zabus defines as "a Third Code" (2007): a category deeply rooted in the spatial concept of the "Third World" ${ }^{8}$ Therefore, the language -

${ }^{8}$ In this respect, as Chantal Zabus states: "The 'Third World', as the site of this third code, may well turn out to be the privileged site for the artful coexistence of postcolonial syncretism, the increased 'diversification' of its literatures and the valorisation of its 'inter- 
both the Portuguese language and the literary code - of Couto's writing corresponds to a "translated otherness" (Brugioni 2012) - or, in other words, to a difference - neutralizing the logic of linguistic and cultural authenticity, and underlying the coexistence of different symbolically and politically connoted languages that are inscribed within the literary text written in Portuguese.

However, it is important to emphasize that along with Mia Couto, many other authors could have been read in this text to demonstrate a variety of "epistemological experiences" (García Canclini 2012, 50) that reveal how the "language thinks itself" (Apter 2006, 11) in the writing of a number of different authors, and to thus illustrate a considerable diversity of aesthetic practices of translating cultural meanings and political understandings.

In the impossibility of presenting a complete overview of this variety, I would like to mention - as the final part of the reflection proposed in this text - two authors from two different Portuguesespeaking African countries - Ruy Duarte de Carvalho and João Paulo Borges Coelho - whose literary work draws attention to the use of translation as a metaphor and an epistemological strategy but with aesthetic and critical results that are very different from the ones emphasized by the work of Mia Couto.

As far as the literary work of João Paulo Borges Coelho is concerned, it can be easily noticed how translation corresponds to a significantly different strategy from that which characterizes Mia Couto's literary project. In fact, when observing the body of work published by Borges Coelho, ${ }^{9}$ one of the most evident features of his writing is suggested by a very normative use of the Portuguese language, avoiding the kind of linguistic hybridizations

national' languages, which will vie with their 'international' European counterparts. This conflict is already being waged in the palimpsest, which is here heralded as the major icon of cross-cultural syncreticity and linguistic métissage, in non-Western literature and criticism" $(2007,11)$.

9 João Paulo Borges Coelho is Professor of African History at the University Eduardo Mondlane, in Maputo. About the way he intends the relation between his literary work and his work as a historian, see Borges Coelho 2009 and 2010. 
or, as defined above in this text, "the translated otherness" that characterizes Couto's writing. However, the normative linguistic style chosen by Borges Coelho in his novels does not undermine the importance of translation as a critical and conceptual framework to (re)present a specific cultural and social environment. This aspect is especially evident in his first book, As Duas Sombras do Rio [The Two Shadows of the River] (Borges Coelho 2003), a novel about the civil war in Mozambique, where the story is set in a very peculiar area of the national territory, the Zumbo region, and in the area of the Zambezi river.

Due to the variety of cultural specificities found in the book $^{10}$ - characters, objects, beliefs, tradition, and places -, the novel proposes very accurate historical representations, where a particular cultural and social environment is described in detail with recourse to a translation into the Portuguese language of these elements, situations and imaginary. Avoiding the process of linguistic métissage, as Chantal Zabus would say (2007), the novel approaches the specificities of this cultural and spatial location through a realistic style of narration, where the translation of other narratives and cultural repertoires - local memories, traditions and other orders of knowledge $-{ }^{11}$ is achieved by means of description and transposition that does not happen within the language, but as a narrative process that constitutes the essential step in order to trans-late - transmit and transfer - cultural meanings and their difference. In this sense, the epistemological roles of exposition and description are one of the essential aspects of Borges Coelho's literary writing. Translation is undertaken as a narrative transposition, in that the use of a normative language is one of the means to (re)present, understand and recognize the multiple diversity that constitutes a specific context and its cultural repertoire and imaginary. Furthermore, in Borges Coelho's literary work, this kind of epistemological use of translation is linked with the

\footnotetext{
${ }^{10}$ In this respect, see: Mendonça 2011, Can 2015.

${ }^{11}$ Regarding this aspect see: Can 2015.
} 
literary and theoretical paradigm of the border, which represents a significant spatial and critical conceptualization within his whole literary work ${ }^{12}$ and further helps define translation as the building process of a mutual space of intelligibility not characterized by erasure or hybridity, but instead by an articulation of difference (Appiah 1993, Sousa Ribeiro 2012).

On another perspective, Ruy Duarte de Carvalho takes a similar approach to that of Borges Coelho. His literary project is not characterized by linguistic hybridization of the Portuguese language, and it suggests a complex critical reflection around the very meaning of language within a postcolonial situation. In other words, as with Borges Coelho, but through a different aesthetic strategy, in Ruy Duarte's literary work the way "language thinks itself" (Apter 2005) is a process of translation and transposition of the oral matrix and tone of the different languages, cultural repertoires and imaginaries that co-exist with the Portuguese language in the Angolan territory (Chaves \& Macêdo 2007). ${ }^{13}$ In this process, the border - with its multiple meanings - represents a theme and a critical paradigm ${ }^{14}$ which is crucial to expose the so called "oral tradition(s)" as a crucial element of a different order of knowledge and particularly of the local and cultural memory (Carvalho 2008, 47-63). On this topic, Luís Quintais states:

\section{[...] the fascination with the border (the border between Angola and Namibia), the border between deserts, the Namib and Kalahari, the boundaries between genres (poetry, fiction, essay, travelogue). The border (and the hybridization it suggests) is not only something that can be}

\footnotetext{
${ }^{12}$ In the book As Duas Sombras do Rio, the Zambezi river represents the emblematic border between the worlds depicted in the novel.

${ }^{13}$ In this respect, see the novels Os Papéis do Inglês (Carvalho 2000) and Vou lá Visitar Pastores (Carvalho 1999).

${ }^{14}$ Regarding this aspect see: Carvalho 2006, Chaves 2006.
} 
attributed to the fact that we are dealing with a writer who resorts to a differentiated and, in many respects, strongly contrasted world view. The border is something that is part of the fabric of experience. $(2006,18 \text {; my translation })^{15}$

Once again, it is not the process of linguistic invention and lexical manipulation that characterizes the translation into the Portuguese language of what Ruy Duarte himself defines as "africanidade e angolanidade" [africanity and angolanness] (Carvalho 2008). Particularly in his poetry, ${ }^{16}$ this process of translation is achieved by "transporting the dynamics of the oral system into the territory of mine [his] personal expression and experience, therefore into the writing in the Portuguese language" (Carvalho 2008, 50; my translation) without any attempt of syntactic or lexical manipulation of the Portuguese language which, in his view, correspond to an extremely problematic technique that, ultimately, is put forward in order to "produce an artificial African otherness" (50; my translation and emphasis).

Adaptation and (re)conversion of the oral repertoire(s) - as a system of knowledge and a structure of thought - constitute the matrix of Ruy Duarte's literary project (Chaves 2006) where translation represents one of the vital steps in the process of inscription, fixation and legitimization of the oral knowledge and culture into the writing world. Therefore, according to this perspective, the epistemological value of translation in literary writing appears evident, emphasising its productive ambiguity within the creative attempt of writing the other and its difference.

\footnotetext{
${ }^{15}$ Original quote: "[O] fascínio pela fronteira (a fronteira entre Angola e Namíbia), a fronteira entre desertos, o Namibe e o Kalahari, a fronteiras entre gêneros (poesia, ficção, ensaio, travelogue). A fronteira (e a hibridização que ela convoca) não é apenas algo que pode ser remetido para o facto de estarmos perante um escritor que faz apelo a lógicas de constituição do mundo, diferenciadas e, em inúmeros aspectos, fortemente contrastadas. A fronteira é algo que faz parte do tecido da experiência" (Quintais 2006, 18).

${ }^{16}$ In this respect, see Lavra. Poesia Reunida 1970/2000 (Carvalho 2005).
} 
In conclusion, counterpointing these diverse strategies of translation seems to be essential in order to highlight the variety of creative practices that are inscribed in the so-called "Lusophone African Literatures", to promote a wider definition of what has been defined as the "Postcolonial Literary Canon" (Parry 2004), and thus tackle the writing from other margins as a theoretical framework to reground paradigms and concepts through which we critically read texts and cultural representations within the Portuguese-speaking world. Therefore, translation and its critical ambiguities contribute to the emergence of new and alternative counterpoints between critical discourses and disciplines within the Humanities, facilitating the occurrence of theoretical paradigms and conceptual constellations that are capable of providing answers to the "multiple spatiotemporal (dis)orders" (Sassen 2000) that the postcolonial condition comprises and (re)presents.

\section{Acknowledgements}

I would like to thank Professor João Ferreira Duarte, Professor Ana Gabriela Macedo and Professor David Brookshaw for their readings and suggestions to this article. 


\section{References}

Afropolitan Magazine: http://www.afropolitan.co.za. Johannesburg, South Africa. Acesso em 20 de junho de 2016.

Agamben, Giorgio. Quel che resta di Auschwitz. L'archivio e il testimone. Milano: Bollati Boringhieri, 1998.

. Homo Sacer. Il potere sovrano e la nuda vita. Torino: Einaudi, 1995.

. Il linguaggio e la morte. Un seminario sul luogo della negatività. Torino: Einaudi, 1982.

Ahmad, Aijaz. In Theory: Classes, Nations, Literatures. London \& New York: Versus, 1992.

$\overline{1-20 .}$

. "The Politics of Literary Postcoloniality." Race \& Class 36.3 (1995):

Ahmed, Sara. Strange Encounters: Embodied Others in Post-coloniality. New York: Routledge, 2000.

Apter, Emily. The Translation Zone. A New Comparative Literature. Princeton: Princeton University Press, 2006.

Appiah, Kwame A. “Thick Translation.” Callaloo 16.4 (1993): 808-819.

Balandier, George. "La situation coloniale: Approche théorique." Cahiers internationaux de sociologie 11.51 (1951): 44 -79.

. Préface em Smouts, M-C. (Org.) La Situation postcoloniale. Paris:

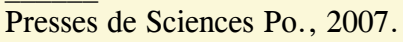

Bandia, Paul. Translation as Reparation. Writing and Translation in Postcolonial Africa. New York: Routledge, 2008. 
Bassnett, Susan; Trivedi, Harish. Post-Colonial Translation: Theory and Practice. London: Routledge, 1999.

Basto, Maria-Benedita. A Guerra das Escritas. Literatura e Nação em Moçambique. Viseu: Vendaval, 2006.

Bhabha, Homi K. The Location of Culture. London: Routledge, 1994.

Blanchard, Pascal; Bancel, Nicolas; Lemarie, Sandrine. La Fracture coloniale. La Société française au prisme de l'heritage colonial. Paris: La Découverte, 2005.

Borges Coelho, João Paulo. As Duas Sombras do Rio. Lisboa: Editorial Caminho, 2003.

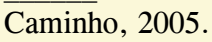

. Índicos Indícios - Meridião e Setentrião. (2 vols). Lisboa: Editorial . "Entrevista com João Paulo Borges Coelho, por Rita Chaves." VIA $\overline{A T L \hat{A N T}}$ TICA 16 (2009): 151-166.

. "A Literatura e o léxico da pós-colonialidade. Uma Conversa com João Paulo Borges Coelho por Elena Brugioni,” Diacrítica 24.3 (2010): 427-444.

Bourdieu, Pierre. The Field of Cultural Production: Essays in Art and Literature. New York: Columbia University Press, 1993.

Brugioni, Elena. "Old empires, new cartographies: problematizing 'lusophone categorizations'." Europe in Black and White. Imigration, Race, and identity in the 'Old Continet. Eds. Ribeiro S. M., Ferreira D. J., Clara F. and Martins L. Bristol, UK / Chicago, USA: Intellect Book (2011): 199-208.

. Mia Couto. Representação, História(s) e Pós-colonialidade. Vila Nova de Famalicão: Húmus Edições-CEHUM, 2012.

- "Narrando $\mathrm{O}(\mathrm{s})$ Índico(s). Reflexões em torno das 'geografias transnacionais do imaginário'.” In Brugioni, Elena, Passos, Joana (eds.) Dossier Narrando o Índico in Diacrítica - Literatura 27.3 (2013): 121-137. 
Can, Nazir A. Discurso e Poder nos romances de João Paulo Borges Coelho. Maputo: Alcance Editores, 2015.

Carvalho, Ruy Duarte de. Vou lá Visitar Pastores. Lisboa: Cotovia, 1999.

. Os Papéis do Inglês. Lisboa: Cotovia, 2000.

. Lavra. Poesia Reunida 1970/2000. Lisboa: Cotovia, 2005.

. "Falas \& vozes, fronteiras \& paisagens ... escritas, literaturas e entendimentos.” Setepalcos. Coimbra: Cena Lusófona 5 (2006).

. A Câmara, a escrita e a coisa dita...fitas, textos e palestras. Lisboa: Cotovia, 2008.

Chaundhury, Kirti N. Asia before Europe: Economy and Civilization of the Indian Ocean from the rise of Islam to 1750. Cambridge: Cambridge University Press, 1990.

Chaves, Rita; Macêdo, Tania. Literaturas de língua portuguesa. Marcas $e$ Marcos. Angola. São Paulo: Arte \& Ciência, 2007.

Chaves, Rita. "Desmedida: O Brasil, para além da paisagem, em Ruy Duarte de Carvalho." Remate de Males 26.2 (2006): 279-291.

. “A Ilha de Moçambique: Entre as Palavras e o Silêncio." Available at: http://www.macua.org/coloquio/A_ILHA_DE_MOCAMBIQUE.htm, 2002.

Couto, Mia. Se Obama fosse africano? E Outras interinvenções. Lisboa: Caminho, 2009.

Falconi, Jessica "Literaturas Africanas, língua portuguesa e pós-colonialismos." In Brugioni, Elena et al. (Orgs.) Itinerâncias. Percursos e Representações da Pós-colonialidade|Journeys. Postcolonial Trajectories and Representations. Vila Nova de Famalicão: Húmus Edições-CEHUM (2012): 203-218. 
. “'Para Fazer um Mar’. Literatura Moçambicana e Oceano Índico.” Eds. Brugioni, Elena and Passos, Joana. Dossier "Narrando o Índico. Diacrítica Literatura 27.3 (2013): 77-92.

Ferreira, Ana Paula. "Specificity without Exceptionalism: Towards a Critical Lusophone Postcoloniality." Postcolonial Theory and Lusophone literatures. Ed. De Medeiros, Paulo. Utrecht, Portuguese Studies Centre (2007): 21-40.

Firmino, Gregório. A questão linguística na África pós-colonial: o caso do português e das línguas autóctones em Moçambique. Maputo: Promédia, 2002.

Freyre, Gilberto. Casa-grande \& senzala: formação da família brasileira sob o regimen de economia patriarchal. Rio de Janeiro: Maia \& Schmidt, 1933.

García Canclini, Néstor. A Sociedade sem Relato. Antropologia e Estética da Iminência. São Paulo: EDUSP, 2012.

Garuba, Harry. "The Critical Reception of the African Novel." The Cambridge Companion to the African Novel. Ed. F. Abiola Irele. Cambridge: Cambridge University Press (2008): 243-262.

Gonçalves, Perpétua. A Génese do Português de Moçambique. Lisboa: Imprensa Nacional-Casa da Moeda, 2010.

Hallward, Peter. Absolutely Postcolonial. Writing between the Singular and the Specific. Manchester: Manchester University Press, 2001.

Hitchcock, Peter The Long Space. Transnationalism and Postcolonial Form. Stanford: S.U. Press, 2010.

Hofmeyr, Isabel. "The Black Atlantic Meets the Indian Ocean: Forging New Paradigms of Transnationalism for the Global South - Literary and Cultural Perspective. Social Dynamics 33.2 (2007): 3-32.

Huggan, Graham. The Postcolonial Exotic. Marketing the Margins. London \& New York: Routledge, 2001. 
Leite, Ana Mafalda. Literaturas Africanas e Formulações Pós-Coloniais. Lisboa: Edições Colibri, 2003.

Lionnet, Françoise and Shih, Shu-mei (eds.) Minor Transnationalism. Durham and London: Duke University Press, 2005.

Mbembe, Achille. "Afropolitanism." Africa Remix: Contemporary Art of a Continent. Eds. Njami, Simon \& Lucy Durán. Johannesburg: Johannesburg Art Gallery (2007): 26-30.

Mendonça, Fátima. Literatura Moçambicana, as dobras da escrita. Maputo: Ndjira, 2011.

Noa, Francisco. "O Oceano Índico e as rotas da transnacionalidade na poesia moçambicana." Working paper available at: http://cesab.edu.mz/, 2012.

. "L'océan Indien et les routes de la transnationalité dans la poésie mozambicaine." Études Littéraires Africaines - Dossier Littératures de l'Angola, du Mozambique et du Cap-vert (Ed. Maria-Benedita Basto) 37 (2014): 73-88.

Parry, Benita. "The Institutionalisation of Postcolonial Studies.” In Lazarus, Neil (ed.) The Cambridge Companion to Postcolonial Literary Studies. Cambridge: Cambridge University Press (2004): 66-82.

Pratt, Mary Louise. Imperial Eyes: Travel Writing and Transculturation. London: Routledge, 1992.

Quintais, Luís. "O olhar do rinoceronte - ou o Ruy como eu o vejo." Setepalcos. Coimbra: Cena Lusófona 5 (2006): 18.

Rama, Angel. "Dez problemas para o romancista latino-americano." Angel Rama. Literatura e cultura na América Latina. Eds. Aguiar, Flávio; Vasconcelos, Sandra. São Paulo: EDUSP, 2001.

Robinson, Douglas. Translation and Empire. Postcolonial Theories Explained. New York: Routledge. 2014 [1997]. 
Sassen, Saskia. "Spatialities and Temporalities of the Global: Elements for a Theorization". Public Culture 12 (2000): 215-232.

Spivak, Gayatri Chakravorty. Outside in the Teaching Machine. New York: Routledge, 1993, p. 202.

Sousa Ribeiro, António. "Vítima do próprio sucesso? Lugares Comuns do Pós-colonial." Itinerâncias. Percursos e Representações da Póscolonialidade|Journeys. Postcolonial Trajectories and Representations. Eds. Brugioni, Elena et al. Vila Nova de Famalicão: Edições Húmus (2012): 39-47

Wainaina, Binyavanga. I am a Pan-Africanist, not an Afropolitan. Plenary Lecture at $A S A U K$ Conference, Leeds University, 6-8th September 2012 (unpublished text).

Zabus, Chantal. The African Palimpsest. Indigenization of Language in West African Europhone Novel. Amsterdam \& New York: Rodopi, 2007.

Recebido em: 10/06/2016

Aceito em: 23/09/2016 Publicado em janeiro de 2017 